EESTI NSV TEADUSTE AKADEEMIA.TOIMETISED 1953. II k., nr. 4 ИЗВЕСТИЯ АКАДЕМИИ НАУК ЭСТОНСКОИ ССР 1953. Том II, \& 4

\title{
НЕКОТОРЫЕ МОРФО-ФИЗИОЛОГИЧЕСКИЕ ПОКАЗАТЕЛИ ПОРОД КРУПНОГО РОГАТОГО СКОТА ЭСТОНСКОЙ ССР
}

\author{
А. и. пунг, \\ доктор сельскохозяйственных наук
}

В последнее время зоотехническая наука при изучении сельскохозяйственных животных и их конституции, кроме внешнего осмотра, пользуется также более точными методами познания структуры и функций отдельных органов и их систем, а также различных желез, оказывающих влияние на тип конституции и продуктивность животных. Эти методы были использованы нами при изучении особенностей и качеств эстонских пород крупного рогатого скота. Чтобы охарактеризовать интерьер коров эстонских пород крупного рогатого скота், мы подвергли изучению строение и микростроение черепов, пястной кости, кожи, а также соотношение важнейших органов и, кроме того, определили некоторые морфологическне показатели крови.

\section{МЕТОДИКА ИССЛЕДОВАНИЯ}

Для исследования мясных качеств эстонских пород крупного poraтого скота и получения образцов для гистологических исследований мы организовали на мясокомбинатах экспериментальный забой скота. Подопытными животными являлись выбракованные из стада колхозов и совхозов, сданные в порядке обязательных поставок, не откормленные и не подготовленные к убою породные животные, имеющие лучшую упитанность. Экспериментальный забой и взятие гистологических образцов происходило по следующей методике: животное взвешивалось и измерялось до забоя, после чего оглушалось имевшимися на бойне средствами. После забоя, производимого на Тартуском мясокомбинате вертикально, а на дру. гих мясокомбинатах горизонтально, определялось количество вытекшей крови, затем отдельно взвешивались голова, ноги, кожа и внутренние органы, определялось количество внутреннего сала и взвешивалась мясная туша. Полученные при забое данные разрабатывались в разрезе пород, после чего вычислялись соответствующие показатели.

Толщина и качество кожн определялись у животных до забоя, путем измерения штангенциркулем и прощупыванием рукой на середине последнего ребра и у локтевого отростка. Для определения толщины кожу животного в названных местах оттягивали палыцами и, поместив ее вдвойне между ножками штангенциркуля, измеряли два-три раза. Общую поверхность кожи определяли по разработанному Е. А. Арзуманяном методу $\left({ }^{3}\right)$ : измеряли общую длину туловнща (от седалищного бутра до 
междурожья) и обхват передней-трети туловища. Полученную путем перемножения указанных промеров площадь увеличивали на $4 \%$.

Взятые для морфологических исследований образцы обрабатывались следующим образом.

1. Че ре п п прежде всего освобождались от мягких частей и взвешивались, после чего проваривались для удаления жира и других органических веществ и затем измерялись соответственно методу, разработанному академиком Е. Ф. Лискуном $\left({ }^{18}\right)$ н В. С. Сивником $\left({ }^{24}\right)$. Полученные промеры сравнивались между собою и сопоставлялись с данными измерений, полученными А. М. Миддендорфом (21) и Е. Аренандером (26), а также с промерами черепов, находящихся в Музее животноводства имени Е. Ф. Лискуна.

2. Пястные кости подвергались первоначальной обработке, взвешивались, а затем варились для удаления жира и органических вешеств. Измерялась длина кости, поперечный и продольный диаметры и обхват в наиболее узком месте. Кость перепиливалась посередине, определялся диаметр костно-мозговой полости и толщина костной стенки. Для гистологического исследования изготовлялись шлифы поперечных разрезов кости, которые исследовались микроскопически. Исследовалась общая структура строения кости, система гаверсовых каналов и строение ламеля. Определялось количество гаверсовых каналов в поле зрения микроскопа при увеличении в 100 раз в десяти местах шлифа, нзмерялся диаметр гаверсовых каналов и их систем. Таким путем определялось количество гаверсовых каналов и их диаметр по отношению к определенной единице площади. Полученные данные сравнивались в разрезе пород.

3. Для гистологического исследования кожи от забитых подопытных животных брались образцы в двух местах: с участка крестца около корня хвоста и на груди, у разреза напротив локтевого отростка. Полученный материал фиксировался $10 \%$ раствором формалина. Микроскопические препараты поперечного разреза кожи изготовлялись в среднем толшиной в 12 мнкронов и окрашивались гематоксилин-эозином и гематоксилин-суданом. Определялось соотношение толщины отдельных слоев кожи, исследовалась толщина коллагеновых пучков и характер их расположения в сетчатом ретикулярном слое. Толшина коллагеновых пучков измерялась при помощи окулярмикрометра. Особое внимание уделялось исследованию потовых и сальных желез кожи, их строению и густоте расположения. Для определения густоты расположения потовых желез устанавливалось их количество в поле зрения микроскопа. При помощи окулярмикрометра определялась длина и толщина потовых желез, а также их строение и форма. При исследовании сальных желез хорошие результаты дала окраска препаратов гематоксилин-суданом; особое вниманне при исследовании уделялось описанию формы желез.

4. Для выяснения в е с о в о го с оотн о шен и я отдельных органов и частей тела у подопытных животных учитывался вес головы, ног, кожи, желудков (без содержимого), кишек (без содержимого), сердца, легких, печени, селезенки, почек, вымени, мошонки, внутреннего сала и мясной туши. Вычисление весового соотношения отдельных органов и частей тела производилось в процентах к предубойному живому весу животного.

5. При исследовании физиологических показателей особое внимание обращалось на кровообращение и кровь. Для этого летом 1951 г. было проведено определение показателей крови дойных коров в высокопродуктивных стадах Вяндраской опытной станции Института животноводства и ветеринарии АН ЭССР и в совхозах «Пяривере» и «Удева» Министерства совхозов ЭССР. Для исследования крови были выбраны животные с различным уровнем продуктивности, в возрасте 
от 5 до 10 лет, со дня отела до пятого месяца лактации. Измерялась температура тела коров, частота пульса в минуту, давленне крови, частота дыхания. Кровь бралась из вены наружной стороны уха иглою Франка. Кровь и приготовленные из нее мазки исследовались, вычислялось количество эритроцитов и лейкоцитов и определялась лейкоцитарная формула. Содержание гемоглобнна определялось по методу Сали. Полученные показатели дают предварительную картину состава и качества крови коров эстонскнх пород скота. Пронзведенные в этой области исследования являются первыми в условиях нашей республики.

\section{РЕЗУЛЬТАТЫ ИССЛЕДОВАНИИ}

\section{I. Строение череnа}

В качестве непременного элемента многих зоотехнических исследований используются соответствующие краниологические материалы. Краниологический метод не только помогает нам решать вопросы пронсхождения животных, но и дает возможность определить среду, в которой развивалась исследуемая порода $\left({ }^{6}, 7,16-18\right)$.

На основании материала обследования комолого скота, проведенного А. Мидлендорфом и др. в северной России в 1883-1884 гг., мы отобрали и обработали данные промеров 10 черепов взрослых комолых коров. Әти промеры в абсолютных и относительных цифрах приведены в таблице 1 , в которой представлены сравнительные краниологические данные по нескольким группам комолого скота в нх историческом развитии. Для сравнения приводятся промеры 10 черепов взрослых коров фьеллской породы из северной Швеции, собранные Е. О. Аренандером $\left({ }^{26}\right)$. Для характеристики черепов балтийского комолого скота мы нспользовали материалы, собранные академиком Е. Ф. Лискуном в 1914-1915 rr., находящиеся в настоящее время в Москве, в Музее животноводства имени Е. Ф. Лискуна. Из этих материалов мы измерили 8 черепов комолых коров эстонского происхождения. Для измерения черепов скота современной эстонской местной породы нами были взяты на мясокомбинате 8 черепов комолых коров. Қроме того, мы измерили, также на мясокомбинате, черепа двух коров эстонской красной породы и двух коров эстонской чернопестрой породы. Индексы промеров черепов коров приводятся в таблице 2 .

При выработке методики измерения черепов мы исходили из исследований А. Миддендорфа ( $\left.{ }^{21}\right)$, что было необходимо для проведения соответствующих сравнений. Руководствуясь трудами Е. Ф. Лискуна $\left({ }^{17 .}{ }^{18}\right)$ и учитывая работы В. С. Сивчика $\left({ }^{24}\right)$, мы дополнили промеры А. Мнддендорфа еще тремя промерамн. Мы брали всего по 35 промеров, что .вполне достаточно для выявления особенностей черепов.

Для нллюстрацин данных в таблицах 1 и 2 приводятся фотоснимки (рис. 1).

Результаты измерений черепов показывают, что в течение 35 лет тип черепа балтийского комолого скота в части соотношения промеров в основном не изменился, не считая некоторого увеличения размера черепов комолого скота, что видно из роста абсолютных промеров. Пользуясь вычисленным отношением величины промеров к основной длине черепа, можно заметить весьма большое сходство между нашими данными и данными, полученными А. Миддендорфом, Е. Аренандером и Е. Ф. Лискуном. Мы можем констатировать только незначительное увеличение длины лба и относительное укорочение нёба и верхнего ряда 
Сравнение средних промеров

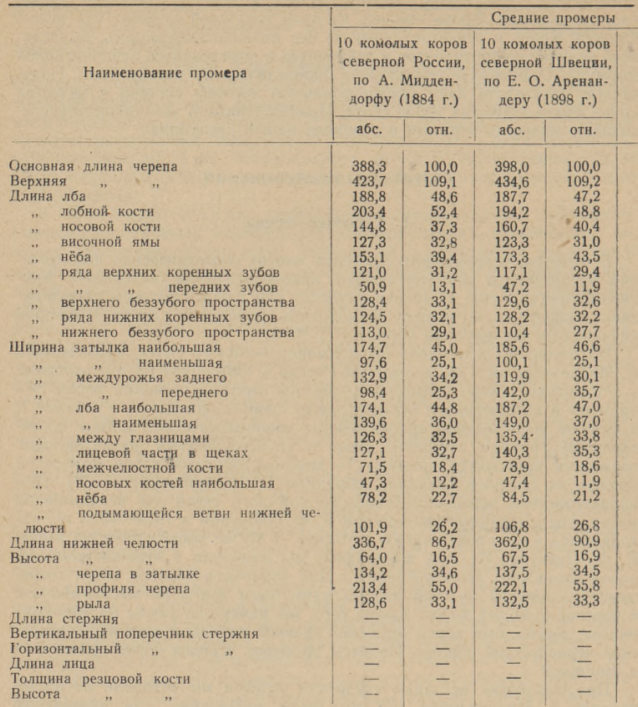

зубов. Заметно также увеличение ширины затылка и уменьшение заднего междурожья. (При установлении последнего промера можно легко ошибиться вследствие отсутствия определенной исходной точки.) Лоб в наибольшей ширнне увеличился, а в наименьшей ширине уменьшился. Характерно расширение лицевой части черепа, заметное по увеличению ширины в щеках. Высота профиля черепа, также как высота морды, увеличилась. Такую же картину показывают вычисленные индексы. Соотношение верхней и основной длины черепа существенно не изменилось, соотношение ширины и длины лба изменилось в сторону увеличения ширины $(92,2-96,6)$. Соотношение наибольшей ширины затылка и наибольшей ширины лба показывает увеличение. Также показывает увеличение соотношение наибольшей ширины лба и основной длины черепа. Но если взять отношение нанменышей ширины лба к ширнне в щечных 


\begin{tabular}{|c|c|c|c|c|c|c|c|c|c|}
\hline \multicolumn{10}{|c|}{ черепов (в миллиметрах) } \\
\hline \multicolumn{2}{|c|}{$\begin{array}{l}8 \text { комолых коров } \\
\text { Прибалтики, из } \\
\text { Музея им. Е. Ф. } \\
\text { Лискуна (1914- } \\
1915 \text { г.) }\end{array}$} & \multicolumn{2}{|c|}{$\begin{array}{l}8 \text { коров современ- } \\
\text { ной эстонской } \\
\text { местнои породн } \\
(1950 \text { г.) }\end{array}$} & \multicolumn{2}{|c|}{$\begin{array}{c}2 \text { коровы } \\
\text { эстонской } \\
\text { красной по- } \\
\text { роды } \\
(1950 \text { г.) } \\
\end{array}$} & \multicolumn{2}{|c|}{$\begin{array}{l}2 \text { коровы совре- } \\
\text { меннои эстонской } \\
\text { чернопестрой п-- } \\
\text { роды (1950 г.) }\end{array}$} & \multirow[t]{2}{*}{ 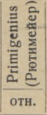 } & \multirow{2}{*}{ 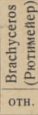 } \\
\hline aбc. & отн. & abc. & отн. & aбc. & отH. & abc. & отн. & & \\
\hline 410,2 & 100,0 & 425,7 & 100,0 & 439,0 & 100,0 & 462,0 & 100,0 & 100,0 & 100,0 \\
\hline & & & $\begin{array}{l}109,0 \\
109,3\end{array}$ & 481,0 & 109,6 & 0 & 112,1 & 111,5 & 112,1 \\
\hline 206,1 & 50,2 & 207 & 48 & 0 & 46,2 & 23 & 51,3 & - & 112,1 \\
\hline 207,6 & 50,6 & 211 & 49 & 0 & 45 & & 51,3 & 49,8 & 51,1 \\
\hline & 41 & & 40 & 0 & 45 & 19 & 43 & 42,0 & 39,4 \\
\hline 129,5 & 31 , & 130 & 30 & 0 & 32 & 13 & 30 & 36,9 & 34,3 \\
\hline & 38 & 165 & 37 & 1 & 39 & & 40 & - & \\
\hline 12 & 30 & 127 & 29 & 125,0 & 28 & 13 & 28 & 28,9 & 30,6 \\
\hline 47 & 11 , & 51 & 12 & & 11 & & 11 & - & - \\
\hline 13 & 32 & & & 15 & 35 & 149 & 32 & 31,6 & 30,7 \\
\hline 131,1 & 32 & $\begin{array}{l}13 \\
13\end{array}$ & 31 & 13 & 31 & 14 & 31 & - & - \\
\hline 103,5 & 25 , & 107 & 25 & 1 & 25 & & 24 & - & \\
\hline 191 , & 46 , & 196 & 46 & 2 & 48 & 21 & 46 & 48,0 & 47,3 \\
\hline 116,2 & 28 & 109 & 25 & 12 & 29 & 13 & 29 & 30,6 & 29,4 \\
\hline & 31 , & 128,8 & 30 & & 31 & 16 & 34 & 36,8 & 36,2 \\
\hline 142,1 & 34 & 144 & 34 & 15 & 35 & 17 & 38 & 41,6 & 38,9 \\
\hline 193 & 47 , & 200,0 & 46 & 21 & 48 & 22 & 47 & 48,0 & 49,5 \\
\hline 153,7 & 37 , & 148,5 & 34 & 15 & 35 & 15 & 34 & - & - \\
\hline 132,1 & 32 & 140 & 32 & 15 & 34 & 16 & 34 & - & - \\
\hline 146 & 35 & 149,2 & 35 & 156 & 35 & 177 & 38 & 34,1 & 35,8 \\
\hline 71 & 17 & $\begin{array}{r}149,2 \\
77,5\end{array}$ & 18 & 85,0 & 19 & 88 & 19 & - & - \\
\hline 50,1 & 12 & 51,0 & 12 & 52 & 11 & 55 & 11 & - & - \\
\hline & 19 & 81,6 & 19 & . & 20 & 89 & 19 & - & \\
\hline 107 & 26 & & 26 & 116,0 & 26 & & 27 & - & - \\
\hline & 91 , & 387,5 & & 406,0 & 92 & 42 & 92 & - & - \\
\hline 58,0 & 14 & $\begin{array}{r}63,5 \\
63,8\end{array}$ & 15 & 64,0 & 14 & 72 & 15 & - & \\
\hline 138 & 33 & & 33 & 141,0 & 32 & 161 & 34 & 34,7 & 36 \\
\hline 232 , & 56 & 242 & 56 & 244,0 & 55 & & 5 & - & . \\
\hline 139,0 & 33 , & $\begin{array}{l}242,2 \\
143,5\end{array}$ & 33 , & 150,0 & 34 & 161 & 34 & - & \\
\hline- & - & & - & 134,0 & 30,5 & 83 & 18 & - & - \\
\hline- & - & $\overline{-}$ & - & 29,0 & & 32 & 6 & - & 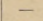 \\
\hline 2478 & $\overline{60.4}$ & - & & 36,0 & 8,2 & & 7,1 & - & \\
\hline $\begin{array}{r}247,8 \\
14,0\end{array}$ & $\begin{array}{r}60,4 \\
3,4\end{array}$ & 254,0 & $\begin{array}{r}60,0 \\
4,0\end{array}$ & 281,0 & 64,0 & 283,0 & 61,3 & - & - \\
\hline $\begin{array}{l}14,0 \\
36,0\end{array}$ & $\begin{array}{l}3,4 \\
8,8\end{array}$ & $\begin{array}{l}16,9 \\
38,8\end{array}$ & $\begin{array}{l}4,0 \\
9,1\end{array}$ & $\begin{array}{r}19,0 \\
3,7\end{array}$ & $\begin{array}{l}4,3 \\
8,4\end{array}$ & $\begin{array}{l}21,0 \\
44,0\end{array}$ & $\begin{array}{l}4,5 \\
9,5\end{array}$ & - & - \\
\hline
\end{tabular}

буграх, то здесь наблюдается уменьшение, что ясно указывает на расширение лицевой-части. Указанные небольшие изменения, несомненно, обусловлены влиянием различных природных и экономнческих факторов.

Приведенные данные показывают, что эстонская местная порода принадлежит к типу северного комолого скота, строение черепа которого одинаково в северной России, Скандинавии и Прибалтике. Этот отличный от других тип скота относится к особой краниологической группе Bos taurus akeratos - и его нельзя отождествлять с другими типами крупного рогатого скота.

Отличие эстонских пород от других типов скота вндно из данных, дриведенных нами для сравнення черепов коров эстонской красной н чернопестрой пород. Қоровы эстонской- красной породы, прежде всего, имеют роговые стержни, меньшую длину лба, более длинную носовую 
Наименование индексов
Верхняя длина черепа

Основная длина черепа

Наибольшая ширина лба

Длина лба

Длнна лба

Длина лица

Нанбольшая ширина затылка

Нанбольшая шнрина лба

Наибольшая ширина лба

Основная длнна черепа

Наименьшая ширина лба

Ширина в щечных буграх

Длина зубного ряда верхней челюсти

Длина беззубого пространства

Ширнна в щечных буграх

Длина лица

Длнна лба

Верхняя длина черепа

\begin{tabular}{|c|c|c|c|c|c|}
\hline 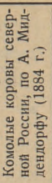 & 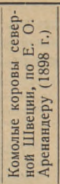 & 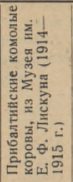 & 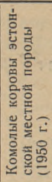 & 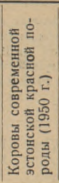 & 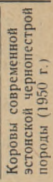 \\
\hline 109,0 & 109,1 & 110,6 & 109,3 & 109,5 & $112,1^{\circ}$ \\
\hline 92,2 & 99,7 & 93,8 & 96,6 & 103,9 & 92,8 \\
\hline- & - & 83,1 & 81,4 & 72,2 & 83,7 \\
\hline 92,4 & 99,1 & 98,7 & 98,0 & 100,0 & 97,2 \\
\hline 44,1 & 47,0 & 47,1 & 47,0 & 48,1 & 47,6 \\
\hline 109,8 & 106,2 & 104,6 & 99,4 & 99,3 & 89,2 \\
\hline 94,2 & 90,3 & 95,0 & 94,4 & 81,1 & 83,5 \\
\hline- & 5 & 59,2 & 58,7 & 55,5 & 62,5 \\
\hline 44,5 & 43,1 & 45,3 & 44,5 & 42,2 & 45,7 \\
\hline
\end{tabular}

кость и боेльшую длину лица. Верхний ряд зубов у них короче и беззубое пространство больше. У этой породы затылок значительно шире, а ширина лба больше по всем промерам. По строению черепа, коровы эстонской красной породы относятся к типу Bos taurus brachyceros. Это подтверждается и вычисленными индексами, показывающими на бо̀льшую величину промеров ширины лба.

Череп коров эстонской чернопестрой породы отличается большим соотношением между верхней и основной длиной черепа. У них лоб значительно длиннее и в то же время у́же, чем у коров красной и местной пород. Отношение длины лба к длине лища больше в пользу длины лба. На более узкий лоб, по сравнению с эстонской красной породой, указывает соотношение нанбольшей ширины лба и основной длины черепа. Отношение наименьшей ширины лба к ширине в щечных буграх меньше всего, что указывает на равномерную узкую голову. Носовая часть шире, чем у какой-либо другой породы. На основании этих показателей коров эстонской чернопестрой породы можно отнести $\mathrm{K}$ типу Bos taurus primigenius. Мы не можем уверенно сказать, что последний точно соответствует типу, опрелеленному Рютимейером, однако равенство относи- 

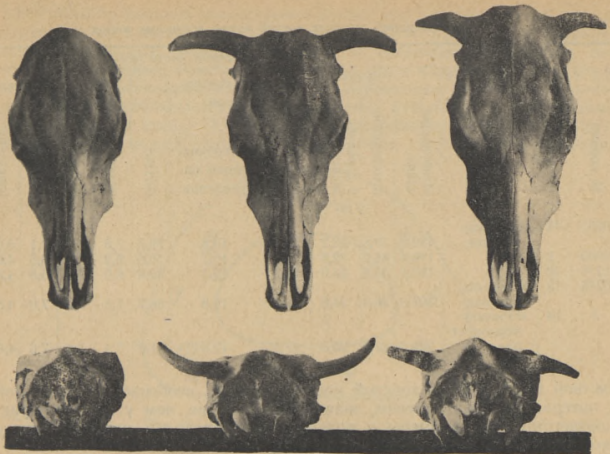

1

2

3

Рнс, 1. Черепа коров эстонских пород крупного рогатого скота. 1 - местная, 2 красная, 3 - чернопестрая.

тельных чнсел указывает на поразительное сходство. Меньше сходства имеется между черепом типа brachyceros, определенным Рютимейером, и черепом коровы эстонской красной породы, хотя основные признаки и здесь довольно сходны.

\section{2. Строение пястной кости}

Для исследования строения костной ткани мы использовали пястные кости, взятые от обследованных нами на мясокомбинатах животных. Пястные кости, прежде всего, измерялись, а затем изучалась их структура,

Приведенные в таблице 3 данные показывают, что пястные кости четырех коров эстонской местной породы имеют почти одинаковые промеры и поэтому представляют довольно однородный исследовательский материал. Пястные кости коров эстонской красной и эстонской чернопестрой пород значительно длиннее, причем их толщина у чернопестрого скота немногим больше, чем у скота местной породы. Вычисляя соотношения поперечного и продольного диаметров, получаем следующие индексы:

Средний индекс коров эстонской местной породы

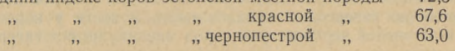

Эти данные показывают, что пястная кость эстонской местной породы более округлая, чем у других эстонских пород. Толщина костной стенки 
Данные измерений пястных костей коров эстонских пород

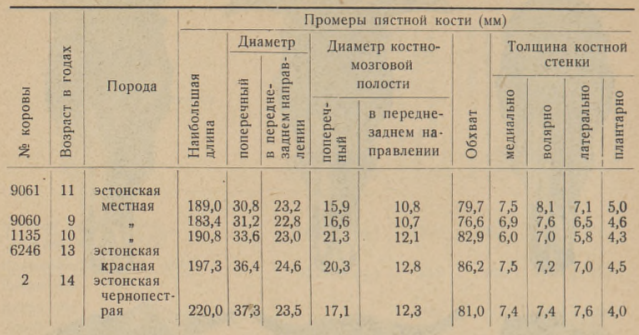

пястной кости коров эстонской местной породы, особенно в медиальной и латеральной части стенки, значительно меньше, чем у других пород. Соответствующие промеры в волярном и плантарном направлениях у скота эстонской местной породы больше.

Для исследования микроскопического строения кости с целью выяснения различий между породами в этом отношении, мы из середины пястной кости выпиливали поперечные шлифы и обследовали под микроскопом системы Гаверса, определяя количество гаверсовых каналов на

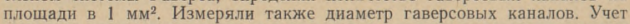
производился в десяти определенных местах шлифа в размере площади поля зрения микроскопа (таблица 4).

Таблица 4

Результаты микроскопического исследования пястной кости

\begin{tabular}{|c|c|c|c|c|c|c|c|}
\hline \multirow{4}{*}{$\begin{array}{l}3 \\
\text { 产 } \\
0 \\
0 \\
0 \\
0 \\
2\end{array}$} & \multirow{4}{*}{ 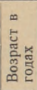 } & \multirow{4}{*}{ Порода } & \multicolumn{5}{|c|}{ Системы Гаверса на плопади в 1 мм² $^{2}$} \\
\hline & & & \multirow{3}{*}{$\begin{array}{c}\text { Число } \\
\text { каналов }\end{array}$} & \multicolumn{4}{|c|}{ Диаметр (в микронах) } \\
\hline & & & & \multicolumn{2}{|c|}{ каналов } & \multicolumn{2}{|c|}{ одной системы } \\
\hline & & & & средн. & пределы & средн. & пределы \\
\hline $\begin{array}{c}9061 \\
9060 \\
6246 \\
2 \\
A^{*}\end{array}$ & $\begin{array}{r}11 \\
9 \\
13 \\
14 \\
-\end{array}$ & $\begin{array}{cl}\text { Эстонская местная } \\
\vdots & \text { красная } \\
\text { Кубанская } & \text { чернопестрая }\end{array}$ & $\begin{array}{l}43,8 \\
38,4 \\
35,4 \\
31,6 \\
48,0\end{array}$ & $\begin{array}{l}17,4 \\
17,4 \\
22,4 \\
21,6 \\
19,4\end{array}$ & $\begin{array}{r}9-33 \\
10-33 \\
12-33 \\
15-33 \\
-\end{array}$ & $\begin{array}{l}115,4 \\
122,0 \\
124,5 \\
128,6 \\
105,8\end{array}$ & $\begin{array}{l}58-207 \\
66-174 \\
67-174 \\
75-183 \\
-\end{array}$ \\
\hline
\end{tabular}

Результаты измерений показывают, что количество каналов на 1 мм² пястной кости у двух коров эстонской местной породы более или менее одинаково; одинаков также диаметр каналов Гаверса $(17,4)$. Диаметр системы ламелей Гаверса показывает небольшие колебания. Значительно различаются соответствующие показатели у коров других пород. Так, количество гаверсовых каналов пястной кости у коров эстонской красной и эстонской чернопестрой пород меньше, но вся гаверсова систе-

* По А. А. Малигонову $\left({ }^{19}, 20\right)$. 
ма и диаметр каналов значительно больше, чем у коров местной породы. Принимая во внимание, что исследованные нами пястные кости принадлежали взрослым коровам, несмотря на небольшое количество подопытных животных, можно сделать вывод, что в микроскопическом строении пястной кости коров имеются породные различия: при большем количестве каналов наблюдается меныший диаметр каналов и меньший размер систем Гаверса (табл. I). Некоторую закономерность можно констатировать также между количеством гаверсовых каналов и их диаметром

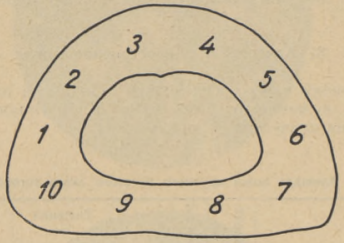

Рис. 2. Схема нсследования микроскопиче. ского строения пястной кости коров эстонских пород скота.

в отдельных местах компактной стенки кости. Нзмерения проводились нами по приведенной на рис. 2 схеме; полученные результаты представлены в таблице 5 .

Таблица 5

Характернстика гаверсовых каналов пястной кости коров эстонских пород скота

\begin{tabular}{|c|c|c|c|c|c|c|c|c|c|c|c|c|}
\hline \multirow{2}{*}{$=\frac{3}{0}$} & \multirow{2}{*}{ Порода } & \multicolumn{11}{|c|}{ Место из мерения } \\
\hline & & 1 & 2 & 3 & 4 & 5 & 6 & 7 & 8 & 9 & 10 & Среднее \\
\hline & & \multicolumn{11}{|c|}{ Число гаверсовых каналов на 1 мм² $^{2}$} \\
\hline $\begin{array}{l}9061 \\
9060 \\
6246 \\
2\end{array}$ & $\begin{array}{l}\text { Эстонская местная } \\
\text { Эстонская красная } \\
\text { Эстонская чернопестрая }\end{array}$ & $\begin{array}{l}40 \\
38 \\
32 \\
28\end{array}$ & $\begin{array}{l}44 \\
40 \\
32 \\
30\end{array}$ & $\begin{array}{l}48 \\
40 \\
38 \\
32\end{array}$ & $\begin{array}{l}50 \\
42 \\
40 \\
38\end{array}$ & $\begin{array}{l}50 \\
38 \\
36 \\
38\end{array}$ & $\begin{array}{l}44 \\
38 \\
32 \\
32\end{array}$ & $\begin{array}{l}44 \\
38 \\
34 \\
30\end{array}$ & \begin{tabular}{l|}
38 \\
38 \\
38 \\
28
\end{tabular} & $\begin{array}{l}40 \\
36 \\
36 \\
30\end{array}$ & $\begin{array}{l}40 \\
36 \\
36 \\
30\end{array}$ & $\begin{array}{l}43,8 \\
38,4 \\
35,4 \\
31,6\end{array}$ \\
\hline & & \multicolumn{11}{|c|}{ Диаметр гаверсовых каналов (в микронах) } \\
\hline $\begin{array}{c}9061 \\
9060 \\
6246 \\
2\end{array}$ & $\begin{array}{l}\text { Эстонская местная } \\
\text { Эстонская красная } \\
\text { Эстонская чернопестрая }\end{array}$ & $\begin{array}{l}18,3 \\
17,4 \\
20,8 \\
22,4\end{array}$ & $\begin{array}{l}16,6 \\
17,4 \\
22,4 \\
24,1\end{array}$ & $\begin{array}{l}16,6 \\
18,3 \\
25,7 \\
21,6\end{array}$ & $\begin{array}{l}16,6 \\
16,6 \\
20,8 \\
19,0\end{array}$ & $\begin{array}{l}17,4 \\
19,1 \\
23,2 \\
21,6\end{array}$ & $\begin{array}{l}19,1 \\
18,3 \\
23,2 \\
21,6\end{array}$ & $\begin{array}{l}18,3 \\
17,4 \\
22,4 \\
20,8\end{array}$ & $\begin{array}{l}18,3 \\
16,6 \\
23,2 \\
21,6\end{array}$ & $\begin{array}{l}16,6 \\
16,6 \\
21,6 \\
19,9\end{array}$ & $\begin{array}{l}18,3 \\
17,4 \\
21,6 \\
23,2\end{array}$ & $\begin{array}{l}17,4 \\
17,4 \\
22,4 \\
21,6\end{array}$ \\
\hline
\end{tabular}

Из таблицы 5 видно, что число каналов увеличивается в волярном направлении кости и уменьшается в плантарном направлении, а диаметр каналов уменьшается в обратном направлении. Незначительность исследуемого материала не дает возможности с достаточной полностью представить эти закономерности.

Сравнивая данные мнкроскопического исследования пястной кости коров эстонских пород с данными А. А. Малигонова и Ф. И. Беднягина $\left({ }^{19}\right)$, находим, что в пястной кости коровы кубанской породы на 
1 мм² $^{2}$ приходилось больше каналов Гаверса, а диаметр одной гаверсовой системы был значительно меньше, чем у коров эстонских пород. Диаметр каналов у этих пород был-почти одинаков. Автору не удалось получить больше данных по другим породам, чтобы сделать соответствующие сравнения. Однако и приведенные данные достаточно ясно указывают на различия между этими породами. На основании этих данных мы можем утверждать, что коровы эстонской местной породы имеют наиболее прочные кости. Пястная кость коров эстонской чернопестрой породы имеет рыхлую, а пястная кость эстонской красной коровы - среднюю структуру.

\section{3. Качество и микростроение кожи}

При исследовании кожи определялась толщина и площадь кожи у живых животных по методу, разработанному Е. Арзуманяном $\left({ }^{3}\right)$. Результаты исследования приведены в таблице 6 .

Таблица 6

Толщина и площадь кожи крушного рогатого скота эстонских пород

\begin{tabular}{|c|c|c|c|c|c|c|c|c|}
\hline \multirow[b]{2}{*}{$\begin{array}{l}\text { Наименование группы } \\
\text { скота (коровы) }\end{array}$} & \multirow{2}{*}{ 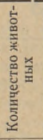 } & \multirow{2}{*}{ 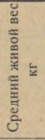 } & \multirow[b]{2}{*}{ 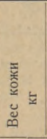 } & \multicolumn{2}{|c|}{$\begin{array}{l}\text { Толщнна } \\
\mathrm{cm}\end{array}$} & \multicolumn{3}{|c|}{$\begin{array}{l}\text { Расчет площади } \\
\text { кожи }\end{array}$} \\
\hline & & & & 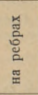 & 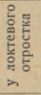 & 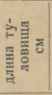 & 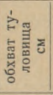 & 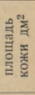 \\
\hline $\begin{array}{l}\text { В хозяй ст в } \\
\text { Вяндраская опытная станция } \\
- \text { чернопестрая порода }\end{array}$ & 8 & 650 & - & 0,56 & 0,26 & 211 & 198 & 435 \\
\hline $\begin{array}{l}\text { Совхоз жУдеваs - эстонская } \\
\text { красная порода }\end{array}$ & 10 & 600 & - & 0,58 & 0,27 & 215 & 218 & 519 \\
\hline $\begin{array}{l}\text { Совхоз жПяривере: - эстон- } \\
\text { ская местная порода }\end{array}$ & 10 & 431 & - & 0,53 & 0,27 & 206 & 183 & 392 \\
\hline $\begin{array}{l}\text { Н а м ясоком } 6 \text { инатах } \\
\text { Эстонская местная порода }\end{array}$ & 5 & 344 & 22,6 & 0,44 & 0,29 & - & - & - \\
\hline Эстонская красная порода & 6 & 441 & 24,3 & 0,49 & 0,37 & - & - & - \\
\hline Эстонская чернопестрая порода & 4 & 508 & 28,8 & 0,49 & 0,35 & - & - & 一 \\
\hline $\begin{array}{l}\text { Бык эстонской красной поро- } \\
\text { ды } 1 \text { г. }\end{array}$ & 2 & 201 & 18,0 & 0,49 & 0,37 & - & 一 & - \\
\hline $\begin{array}{l}\text { Бык эстонской красной поро- } \\
\text { ды } 2 \text { г. }\end{array}$ & 1 & - & 24,0 & 0,50 & 0,40 & - & - & - \\
\hline $\begin{array}{l}\text { Бык эстонской красной поро- } \\
\text { ды } 3 \mathrm{r} \text {. }\end{array}$ & 2 & 475 & 30,8 & 0,50 & 0,42 & - & $\sigma$ & 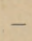 \\
\hline $\begin{array}{l}\text { Телка эстонской красной по- } \\
\text { роды } 1 \text { г. }\end{array}$ & 1 & - & 15,5 & 0,40 & 0,30 & - & - & - \\
\hline $\begin{array}{l}\text { Телка эстонской красной по- } \\
\text { роды } 2 \text { г. }\end{array}$ & 2 & 260 & 20,0 & 0,47 & 0,34 & - & - & - \\
\hline
\end{tabular}

Из приведенных в таблице 6 данных видно, что наиболее тонкую кожу и наименьшую площадь кожи имеет скот эстонской местной породы. В толщине и площади кожи коров эстонской красной и эстонской чернопестрой пород существенного различия не наблюдается, так как измеренные животные в обоих хозяйствах были хорошо развиты и поэтому имели достаточно толстую и большую кожу. Измеренные на мясокомбинатах животные имели меньший живой вес и их кожа была значительно 

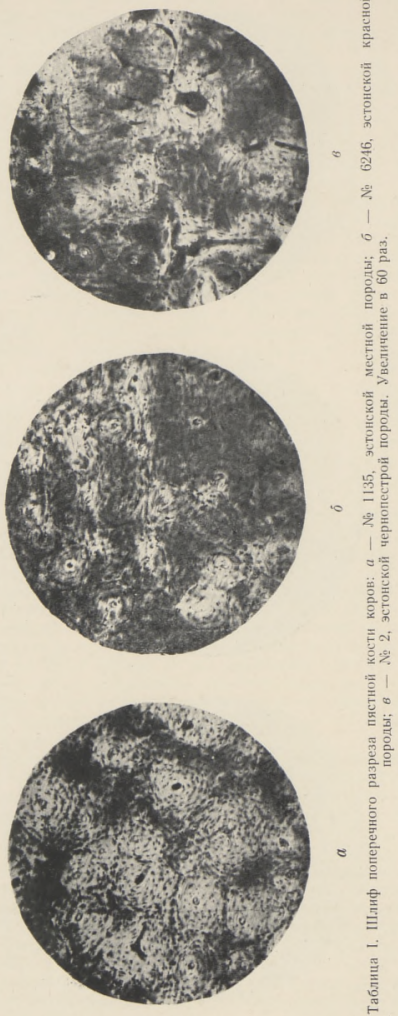
ТАБЛИЦА II
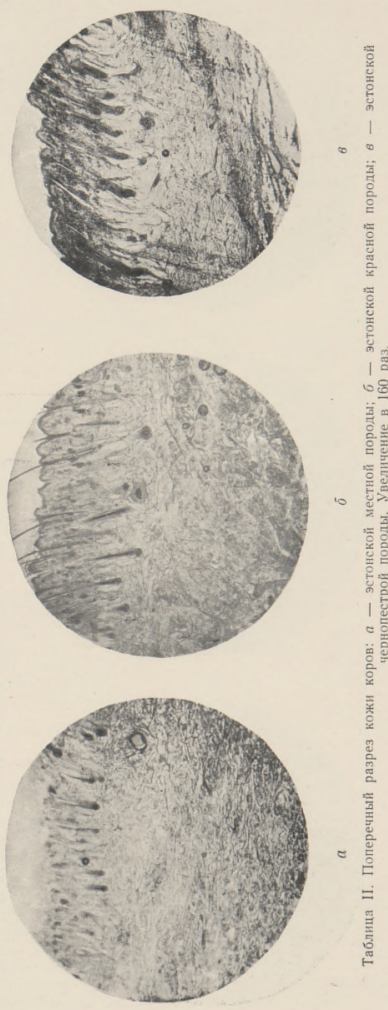
тоньше. Данные измерения кожи коров из стада Вяндраской опытной станции и совхоза «Удева» показывают, что эйрнзомный тип скота дает народному хозяйству наряду с высокой продукцией молока и мяса также и хорошую кожу.

Для гистологического исследования кожи брались образщы в области корня хвоста; препараты кожи изготовлялись по обычной методике. При исследовании кожи коров эстонских пород обращалось внимание на все три основные слоя кожи.

Эпидермис кожи у коров этих лород мало различается, только у коров эстонской чернопестрой и красной породы он значительно толще, чем у коров эстонской местной породы.

Корнум, или собственно кожа, интересовала нас больше, так как от качества этого слоя кожи зависит ее промышленная ценность. Собственно кожа разделяется на два слоя - на верхний папиллярный слой, который без особенно резких границ переходит в сетчатый слой.

В папиллярном слое заложены важные железы, регулирующие температуру и смазку тела, и, кроме того, чувствительные нервы, осуществляющие передачу раздражений. В этом же слое имеется хорошо развитая сеть кровеносных сосудов. В основном папиллярный слой состоит из тонких коллагеновых волокон, которые густой сетью окружают корни волос, железы и мышцы. Папиллярный слой у коров эстонских пород различной толшины, что видно из представленных микрофотоснимков (табл. II). Снимки показывают, что у коров эстонской местной породы этот слой тоньше и его элементы меныше по объему (железы, корни волос); значительно больше этот слой развит у коров эстонской красной породы и еще больше у коров эстонской чернопестрой породы (особенно в части потовых желез). Эти различия заставили нас нсследовать потовые железы каждой из этих пород скота в отдельности.

Назначение потовых желез, по определению А. В. Румянцева $\left({ }^{23}\right)$, состоит в выделенин жирной секрецин для смазывания эпидермиса, выделении воды для отдачи тепла, а также продуктов обмена - белков и белковых веществ, вследствне чего эти железы имеют для организма животного существенное значение. Многие авторы пытались найти зависимость между количеством потовых желез и молочной продуктивностью животных. Так, например, Н. Д. Замятина $\left({ }^{9}\right)$ установила сравнительно высокую корреляцию между количеством потовых желез и продукцией молока $(+0,741 \pm 0,041)$. Исходя из этого, Замятина рекомендует пользоваться наличием потовых желез на единицу поверхности кожи, как одним из исходных моментов при отборе в молочном скотоводстве. Мы, однако, не можем согласиться с Н. Д. Замятиной, так как наши исследования приводят к другим результатам.

Для выяснения количества и величины потовых желез в коже коров эстонских пород крупного рогатого скота мы пользовались поперечными срезами кожи, взятыми из кож забитых на мясокомбинатах коров. По этим срезам были определены количество, величина, расположение и форма потовых желез (таблица 7).

Из таблицы видно, что количество потовых желез кожн в поле зрения микроскопа прн увеличении в 100 раз больше всего у коров эстонской местной породы и меньше всего у коров эстонской чернопестрой породы. Но длина и диаметр потовых желез, чем и характеризуется их величнна, больше всего у коров эстонской чернопестрой породы и меньше всего у коров эстонской местной породы. Приведенные данные ясно указывают на различие в количестве и величине потовых желез. Особенно большая разница в величине потовых желез кожи наблюдается у коров эстонской местной и чернопестрой пород. То обстоятельство, что коровы 
Данные о потовых железах кожи коров эстонских пород

\begin{tabular}{|c|c|c|c|c|c|c|c|c|c|}
\hline \multirow[t]{2}{*}{$\frac{\mathrm{Ng}}{\text { коровы }}$} & \multirow{2}{*}{\multicolumn{3}{|c|}{ Порода }} & \multicolumn{2}{|c|}{$\begin{array}{c}\text { Количество по- } \\
\text { товых желез в } \\
\text { поле зрения } \\
\text { микроскопа при } \\
\text { увеличении в } \\
100 \text { раз }\end{array}$} & \multicolumn{2}{|c|}{$\begin{array}{c}\text { Длина потовых, } \\
\text { желез в микро- } \\
\text { нах }\end{array}$} & \multicolumn{2}{|c|}{$\begin{array}{l}\text { Ширнна пото- } \\
\text { вых желез в } \\
\text { микронах }\end{array}$} \\
\hline & & & & средн. & пределы & средн. & пределы & средн. & пределы \\
\hline \multirow[t]{2}{*}{$\begin{array}{l}1369 \\
9061 \\
9060 \\
1140\end{array}$} & Эстонская & $\begin{array}{c}\text { местная } \\
\text { " } \\
.\end{array}$ & $\begin{array}{c}\text { порода } \\
\text { " } \\
\text { " }\end{array}$ & $\begin{array}{l}9,0 \\
8,5 \\
8,2 \\
8,5\end{array}$ & $\begin{array}{l}8-10 \\
8-9 \\
7-10 \\
8-9\end{array}$ & $\begin{array}{l}570 \\
690 \\
601 \\
558\end{array}$ & $\begin{array}{r}510-600 \\
600-820 \\
350-760 \\
380-620\end{array}$ & $\begin{array}{l}80 \\
86 \\
85 \\
91\end{array}$ & $\begin{array}{l}60-120 \\
70-100 \\
70-110 \\
70-110\end{array}$ \\
\hline & Средние д & данные & & 8,6 & $7-10$ & 605 & $|350-820|$ & 86 & $60-120$ \\
\hline \multirow[t]{2}{*}{$\begin{array}{l}5054 \\
6246 \\
5782\end{array}$} & Эстонская & красная & $\begin{array}{c}\text { порода } \\
. \\
\text { " }\end{array}$ & $\begin{array}{l}7,4 \\
9,6 \\
7,8\end{array}$ & $\begin{array}{l}6-8 \\
8-11 \\
6-9\end{array}$ & $\begin{array}{l}574 \\
571 \\
608\end{array}$ & $\begin{array}{l}450-750 \\
500-830 \\
450-730\end{array}$ & $\begin{array}{r}95 \\
105 \\
104\end{array}$ & $\begin{array}{l}70-120 \\
70-120 \\
80-120\end{array}$ \\
\hline & Средние д & панные & & 8,3 & $6-11$ & 584 & $450-830$ & 101 & $70-120$ \\
\hline \multirow[t]{2}{*}{$\begin{array}{l}2001 \\
7832 \\
8791\end{array}$} & Эстонская & черноп. & $\begin{array}{c}\text { порода } \\
= \\
\end{array}$ & $\begin{array}{l}6,3 \\
7,2 \\
6,8\end{array}$ & $\begin{array}{l}5-8 \\
6-8 \\
6-7\end{array}$ & $\begin{array}{l}751 \\
804 \\
803\end{array}$ & $\begin{array}{l}590-790 \\
620-870 \\
790-870\end{array}$ & $\begin{array}{l}100 \\
117 \\
115\end{array}$ & $\begin{array}{r}80-120 \\
100-160 \\
100-120\end{array}$ \\
\hline & Средние д & данные & & 6,8 & $5-8$ & 786 & $590-870$ & 111 & $80-160$ \\
\hline
\end{tabular}

эстонской чернопестрой породы по сравнению с коровами других эстонских пород имеют более высокую молочную продуктивность, позволяет предполагать коррелятивную связь между площадью или объемом потовых желез и молочной продукцией.

Форма потовых желез кожи коров разных пород различна (табл. III). В коже коров эстонской местной породы потовые железы в большинстве случаев расположены прямо, в одном направлении, и скрученные железы встречаются только в отдельных случаях. Выводные протоки прямые и открываются не непосредственно у корня волос, но немного дальше. В коже коров эстонской красной породы имеются потовые железы двух типов: скрученные железы с 2-3 складками или сегментами (большинство) и прямые железы. Железы в коже коров эстонской чернопестрой породы большей частью с несколькими складками (2-4), расположены дугообразно и размещены около корней волос пучками (гнездами), наподобне потовой железы человека.

В собственно коже тонкие волокна папиллярного слоя, постепенно утолщаясь и складываясь, образуют коллагеновые пучки, которые сплетаются и составляют прочный дермальный слой кожи правильного строения, пронизанный эластичными волокнами, придающими коже упругость. На основании проведенных исследований установлено, что прочность кожи зависит от прочности сплетения и структуры коллагеновых пучков, вследствие чего, с точки зрения качества кожи, этому вопросу следует уделить большое внимание. Другим важным моментом является толщина коллагеновых пучков, от которой также зависит прочность кожи.

В таблице 8 приведены данные измерений толшины коллагеновых пучков по образцам кожи коров эстонских пород, взятых в области корня хвоста. 


\begin{tabular}{|c|c|c|c|c|c|c|c|}
\hline \multirow{2}{*}{$\begin{array}{c}\text { № } \\
\text { коровы }\end{array}$} & \multirow{2}{*}{\multicolumn{3}{|c|}{ Порода }} & \multirow{2}{*}{$\begin{array}{l}\text { Возраст } \\
\text { в годах }\end{array}$} & \multirow{2}{*}{$\begin{array}{c}\text { Вес } \\
\text { кожи } \\
\text { кr }\end{array}$} & \multicolumn{2}{|c|}{$\begin{array}{c}\text { Коллагеновые пучки } \\
\text { (в микронах) }\end{array}$} \\
\hline & & & & & & $\begin{array}{l}\text { средний } \\
\text { диаметр }\end{array}$ & предель \\
\hline \multirow[t]{2}{*}{$\begin{array}{l}1140 \\
9060 \\
9061 \\
1369\end{array}$} & Эстонская & местная поро & & $\begin{array}{r}4 \\
9 \\
11 \\
12\end{array}$ & $\begin{array}{l}24 \\
19 \\
20 \\
25\end{array}$ & $\begin{array}{r}97,1 \\
108,7 \\
101,2 \\
94,6\end{array}$ & $\begin{array}{l}57-116 \\
83-124 \\
57-124 \\
83-116\end{array}$ \\
\hline & В среднем & по 4 корова & & 9 & 22 & 100,4 & $57-124$ \\
\hline \multirow[t]{2}{*}{$\begin{array}{l}6246 \\
5782 \\
5054\end{array}$} & Эстонская & красная поро & & $\begin{array}{r}13 \\
7 \\
10\end{array}$ & $\begin{array}{l}\overline{24} \\
27\end{array}$ & $\begin{array}{l}69,5 \\
68,0 \\
70,2\end{array}$ & $\begin{array}{l}55-82 \\
60-87 \\
60-92\end{array}$ \\
\hline & В среднем & по 3 корова & & 10 & 25,5 & 69,2 & $55-92$ \\
\hline $\begin{array}{l}2001 \\
8791 \\
7832\end{array}$ & Эстонская & чернопестрая & порода & $\begin{array}{l}10 \\
15 \\
15\end{array}$ & $\begin{array}{l}27 \\
30 \\
25\end{array}$ & $\begin{array}{l}83,0 \\
79,7 \\
76,0\end{array}$ & $\begin{array}{l}58-116 \\
66-108 \\
62-92\end{array}$ \\
\hline & В среднем & по 3 коровам & & 13,3 & 27,3 & 79,6 & $58-116$ \\
\hline
\end{tabular}

Из приведенной таблищы видно, что коллагеновые пучки с наименьшим диаметром наблюдаются в коже коров эстонской красной породы, а в коже коров эстонской чернопестрой породы коллагеновые пучки имеют среднюю толщину.

Второй важной задачей исследования кожи было определение закономерностей взаимного сплетения коллагеновых пучков. За основание мы приняли описанные А. В. Румянцевым $\left({ }^{23}\right)$ исследования Брауна, Иванова и Рябина, которые в отношении структуры связи коллагеновых пучков установили три типа строения: первый тип характеризуется многочнсленностыю диагональных пучков, которые, перекрещиваясь друг с другом, образуют ромбовидные фигуры; второй тип отличается отсутствнем ромбов при наличии вертикальных и горизонтальных пучков и третий тип характеризуется горизонтальным сплетением пучков.

По нашим наблюдениям, подтвержденным микрофотоснимками (табл. IV), коллагеновые пучки в коже коров эстонской местной породы располагаются более или менее горизонтально или же под небольшим острым углом, образуя так называемое горизонтальное сплетение.

Коллагеновые пучки в коже коров эстонской красной породы, напротив, расположены под большим углом $\left(45^{\circ}\right)$ и представляют более или менее ясно выраженное ромбовидное расположение (пучки расположены диагонально). Расположение пучков густое, хорошо переплетенное и образует прочный компактный слой собственно кожи.

Коллагеновые пучки в коже коров эстонской чернопестрой породы располагаются под средним углом и образуют слаборомбическое сплетение. У коровы № 7832 можно было констатировать вертикальное расположение пучков.

При оценке качества кожи с точки зрения промышленного использования, наши исследования показали, что более качественной является 
кожа коров эстонской красной и чернопестрой пород, как имеющая лучшее петлистое строение коллагеновых пучков.

Горизонтальное строение кожи скота эстонской местной породы с крупными коллагеновыми пучками, по нашему мнению, не обеспечнвает достаточной плотности кожи и не придает ей нужной прочности. Наш вывод требует еще проверки на кожевенных заводах при дублении кожи.

\section{4. Соотношение отдельных органов и частей тела коров эстонских пород}

Исследование соотношения отдельных органов и частей тела коров эстонских пород при выявлении породных морфологических различий проводилось на мясокомбинатах. В таблице 9 приведены соотношение отдельных органов и частей тела, а также некоторые другие данные о забитых животных. Для вычисления относительных чисел исходили из чистого (предубойного) живого веса, полученного вычетом веса содержимого пищеварительного тракта из общего живого веса животного. Наименьший чистый вес имеют коровы эстонской местной породы (288,2 кг) и самый высокий вес - коровы эстонской чернопестрой породы $(405,2$ кг). Абсолютный вес органов и снстем органов различается у коров отдельных пород в большой мере. Например вес сердца коров эстонской местной породы составляет 1,8 кг, а коров эстонской красной породы - 2,3 кг. Так как абсолютный вес отдельных органов не выражает соотношений с достаточной ясностью, то мы вычислили весовое отношение отдельных органов к чистому живому весу.

Tаблица 9

Соотношение отдельных органов и частей тела коров эстонских пород (в процентах)

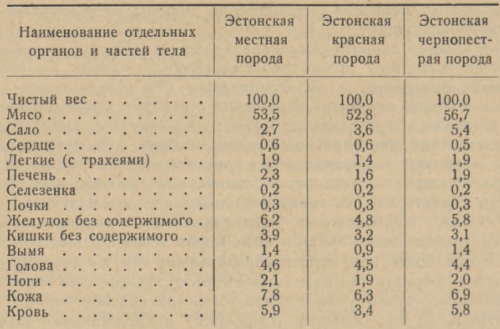

Из приведенных сравнительных данных видно, что скот эстонской чернопестрой породы дает наиболее высокий выход мяса и сала и имеет наилучшие мясные качества. У скота эстонской красной и местной пород существенного различия в мясных качествах не наблюдается.

Относительный вес сердща по породам мало различается; большее различие наблюдается в весе легких, а также печени, желудка и кишек. Относительный вес этих органов является наибольшим у скота эстонской местной породы, за которым следует скот эстонской чернопестрой 
ТАБЛИЦЦА III

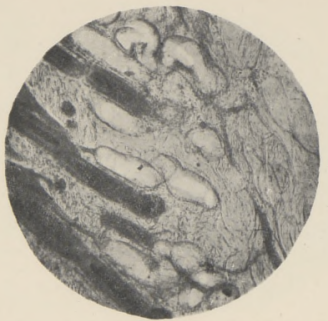

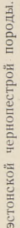
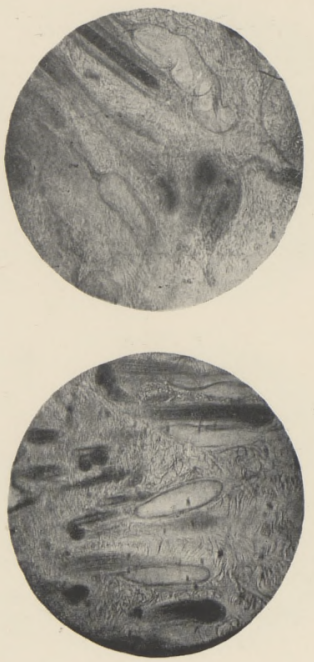

$\because$

鬲

흥플

음

항ㄱ

할 
ТАБЛИЦА IV
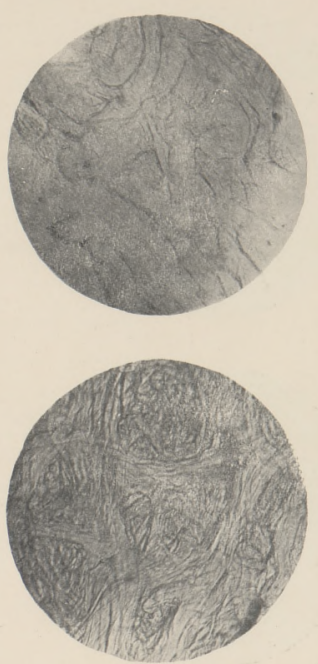

6
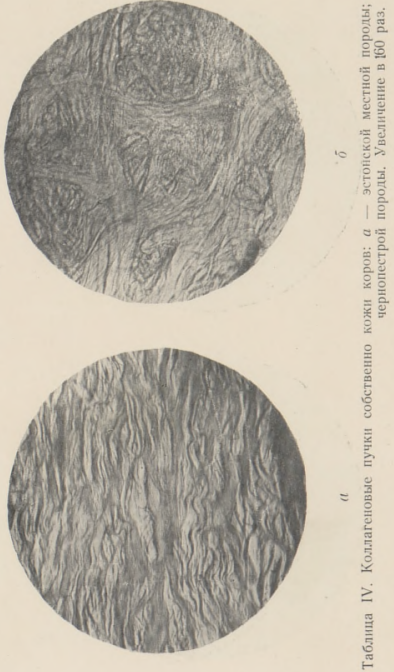
породы. Относительный вес кожи является нанбольшим у скота эстонской местной породы, а наименьшим у скота эстонской красной породы. Веса крови сравнить не удалось, так как забой коров эстонской красной породы производился вертикально, а забой коров других пород - горизонтально.

\section{5. Гематологические показатели коров эстонских пород}

В числе физиологических показателей нами были исследованы показатели крови коров эстонской чернопестрой породы из стада Вяндраской опытной станцин, коров эстонской местной породы из совхоза «Пяривере» и коров эстонской красной породы из совхоза «Удева». Кроме коров этих высокопродуктивных стад, мы дополнительно исследовали показатели крови коров эстонской красной и эстонской чернопестрой пород из совхоза «луунья». Исследование было проведено в августе 1951 г. по описанной выше методике. Полученные результаты надо считать предварительными, так как исследование было однократным и охватывало сравнительно небольшое количество животных. Данные исследования приводятся в таблице 10 .

Tаблица 10

Показатели крови у коров эстонских пород

\begin{tabular}{|c|c|c|c|c|c|c|c|c|c|c|c|}
\hline \multirow[b]{3}{*}{ Породы } & \multirow[b]{3}{*}{ 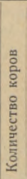 } & \multicolumn{3}{|c|}{ Продукция } & \multirow[b]{3}{*}{ 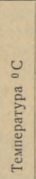 } & \multirow{3}{*}{ 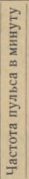 } & \multirow{3}{*}{ 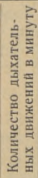 } & \multicolumn{4}{|c|}{ Показатели крови } \\
\hline & & & \multicolumn{2}{|c|}{ 3a $1950 \mathrm{r}$. } & & & & \multirow[b]{2}{*}{ 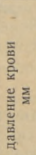 } & \multirow[b]{2}{*}{ 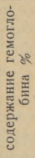 } & \multirow[b]{2}{*}{ 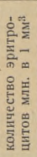 } & \multirow[b]{2}{*}{ 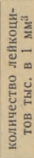 } \\
\hline & & & 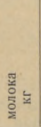 & 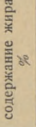 & & & & & & & \\
\hline $\begin{array}{l}\text { стонская местная порода . } \\
\text { стонская чернопестрая по- } \\
\text { рода }\end{array}$ & 10 & 10 & 3833 & 4 , &, 5 & 67 & 32 & 120 & 59 & 6,16 & \\
\hline $\begin{array}{l}\text { а) высокопродуктивные } \\
\text { коровы . } \\
\text { б) среднепродуктнвные }\end{array}$ & 10 & $15-30$ & 5853 & 3,9 & 38,5 & 76 & 28 & 108 & 56 & 5,57 & 7,4 \\
\hline $\begin{array}{l}\text { коровы } \\
\text { а) высокопродуктивные }\end{array}$ & 6 & $10-20$ & 4276 & 3,4 & 38,4 & 68 & 35 & 123 & 52 & 5,96 & 6,2 \\
\hline 6) среднепродуктиввые & 10 & $15-30$ & 7025 & 4,1 & 38,8 & 81 & 39 & 140 & 61 & 6,20 & 6,6 \\
\hline
\end{tabular}

При сравнении полученных данных с данными исследований других авторов $(1,10,12,13,14-15,25)$ выясняется, что коровы отдельных стад эстон ских пород имеют показатели крови, аналогичные показателям крови других пород. Хотя мы, во избежание могущего иметь место различия в составе крови в зависимости от возраста и месяца лактации, подбирали соответствующих животных, все же сравнение между отдельными породами было затруднено вследствие различного уровня молочной продуктивности коров. Как показывают данные наших исследований, коровы-рекордистки эстонской красной породы из стада совхоза «Удева» со средним живым весов $550 \mathrm{kr}$, дающие $7000 \mathrm{kr}$ молока в год и во 
время проведения нсследования 20-30 кг молока в сутки, имеют самые высокие показатели крови. Давление крови у ннх равно 140 мм ртутного столба, содержание гемоглобина в крови $61 \%$, эритроцнтов 6,2 млн. Температура тела, а также деятельность сердца и легкнх у них значительно выше, чем у коров других пород.

Коровы-рекордистки эстонской чернопестрой породы из стада Вяндраской опытной станции имеют значительно более низкие показатели крови. Частота пульса н содержание в крови гемоглобина у них только немногим превышает соответствующие показатели у коров со средним уровнем молочной продуктивности. Количество эритроцитов и давление крови у высокопродуктивных коров эстонской чернопестрой породы ниже, чем у коров этой же породы со средней продуктивностью. Причиной этого могут быть явления анемии, наблюдающиеся при высоких удоях.

Показатели крови у коров эстонской местной породы в большинстве случаев аналогичны показателям крови коров других пород со средней молочной продуктивностью, причем давление крови и содержание гемоглобина у первых немного выше. В отношении количества лейкоцитов у отдельных пород и коров с различным уровнем продуктивности особых расхождений не наблюдается.

Приведенные показатели являются результатом первого исследования крови взрослых коров эстонских пород и их ограниченность не дает возможности сделать более определенные выводы. Для накопления более обширного материала необходимо продолжить исследованне физиологических показателей эстонских пород крупного рогатого скота, применяя более совершенную методику.

На основании наших первых исследований интерьера коров эстонских пород можно сказать, что между отдельными породами имеются резкие различия в отношении строения черепа, пястной кости и кожи. Эстонская местная порода имеет некоторые конституционные преимущества перед другими породами: ее кости прочны, кожа малосекретна, а соотношение отдельных органов по сравнению с другими породами более выгодно. Однако наши исследования не подтверждают того, что кожа коров эстонской местной породы имеет наилучшее качество. Отсутствие данных промышленной обработки кожи не дает возможности для объективной оценки.

Нашей дальнейшей задачей является собирание большего количества материала, на основании которого можно будет комплексно изучить особенности и качества интерьера животных эстонских пород, а также отдельных линий и семейств для более четкого определения конституциональных типов эстонских пород крупного рогатого скота.

Ннститут жсивотноводства и ветеринарии Академии наук Эстонской ССР

Поступила в редакцико 21 VII 1953

\section{ЛИТЕРАТУРА}

1. К. А. А копя.н, Показатели крови у коров разных пород. «Успехи зоотехнических наук», т, IV, вып, II, 97, 1937.

2. Е. Г. Авдреева, Анализ структуры костной ткани в поляризованном свете на прнмере изучения пясти лошади Пржевальского. єТруды Института эволюционной морфологии», т. II, вып. 5, М.-Л., 1939.

3. Е. А. А р з уманян, Методы прижизненного определения качества кожи, «Советская зоотехния», № 3, 1949. 
4. Е. А. А рзуманян, Постэмбриональное развитие кожн крупного рогатого скота, «Советская зоотехння», ㅅ․ 7, 1949.

5. Н. Богдашев, Анатомо-гистологнческое строение и физические свойства элементов пясти некоторых пород лошадей в связи с функцней. Сборник Ленинградского зоотехнического института, вып. I, 1936.

6. С. Н. Боголюб скнй, О некоторых общнх й частных закономерностях онтогенетического развития овеш. Известня АН СССР, $\mathcal{N}_{3} 3,1948$.

7. А. Б р а у н ер, К вопросу об естественно-нсторическом и особенно остеологическом обследовании домашних животных СССР и сопредельных местностей. Труды лаборатории генетики АН СССР, Ленинграл, 1933.

8. Н. А. Д иомидов а, Развитне кожн овец в эмбриональном перноде, єТруды института морфологии животных им. А. Н. Северцоваз, вып. 4, 1951.

9. Н. Д. 3 а м ятина, Оценка молочности животных по потовым железам их кожн. Автореферат диссерташнн, 1949.

10. ПI. А. З во н ко в и ч, Характер нзменення морфологических показателей кровн крупного рогатого скота в связи с возрастом, лактащией и стельностью, «Вестник сельскохозяйственных наук», № $3,1940$.

11. Нсследованне современного состояння скотоводства в Росснн. Рогатый скот, вып. 1-4, Москва, $1884-1893$.

12. А. А. К удрявцев и М. В. К удря ше в, Изменение физнологических и морфологических свойств крови телят в связи с возрастом. еТруды Всесоюзного ннститута экспериментальной ветеринаринь, т. 14, 1936.

13. М. В. К удряшев, Изменение крови у крупного рогатого скота в связи с сезонами года. «Вестник сельскохозяйственных наукљ - ветерннария, вып, I. 1940

14. Х, Ф. К ушне р, Исследование состава крови ярославского скота в связи с его продуктнвностью. Доклады АН СССР, т. X, № 5, 1938.

15. Х. Ф. К у ше н, О составе кровн крупного рогатого скота в связи с его продук. тивностью. Доклады ВАСХНИЛ, вып, 10, 1938,

16. Е. Ф. Лн к ун, Задачи краниологин. С.-Петербург, 1903.

17. Е. Ф. Л нскун, Влияние некоторых воздействий на развптие черепа и костяка животных. «Труды бюро по зоотехнии», вып, II, С.-Петербург, 1910.

18. Е. Ф. Ли и к у н, Методика краниологических исследованнй, «Труды бюро по зоотехнин, вып. III, С.-Петербург, 1910.

19. А. А. М алигонов и Ф. И. Беднягин, Некоторые данные по вопросу о характере сетн таверсовых каналов костной ткани в связи с энергией роста. « Труды Кубанского сельскохозяйственного института», т, IV, Краснодар, 1925.

20. А. А. Малигонов и Г. Ф. Р а сходов, Краткое сообщение о характере роста и строеннн черепа у крупного рогатого скота (калмыцкой и симментальской пород) в связи с предполагаемыми условнями роста. «Труды Кубанского сельскохозяйственного институтаз, т. IV, Краснодар, 1925.

21. А. Ф. Мнддендорф, О породе рогатого скота Северной России и улучшение его. Исследование современного состояния скотоводства в России. Рогатый скот, вып, I, Москва, 1884.

22. В. Н, Ннкнтин, Атлас клеток крови сельскохозяйственных и лабораторных животных. Сельхозгиз, Л., 1949.

23. А. В. Р ум я н е в, Микроструктура кожи и методы ее микроскопического исследования. Гизлегпром, M.- $\mathcal{1}, 1934$.

24. В. С. С ив чик, Зоологическне особенности астраханского (калмыцкого) скота и его потенщиальная скороспелость. Диссертащия, 1948.

25. И. С. Т К ка рь, Возрастные изменения количества лейкоцитов и лейкоцитарные формулы у красного степного скота. Доклады ВАСХНИЛ, вып. 13-14, 1937.

26. E. O. Arena nder, Studien über das ungehörnte Rindvieh im nördlichen Europa unter besonderer Berücksichtigung der nordschwedischen Fjellrasse, nebst Untersuchungen über die Ursachen der Hornlosigkeit. Berichte aus dem physiologischen Laboratorium und der Versuchanstalt der landwirtschaftlichen Institute der Universität Halle. Dresden, 1898. 